\title{
Ainedidaktiikka moninaistuu
}

Keväällä 2019 julkaistiin Opettajankoulutusfoorumin tilaama Selvitys opettajankoulutuksen rakenteesta yliopistoissa. Näyttää siltä, että koulussa opetettavien oppiaineiden didaktiikan professuureja on hyvin vähän ja tehtävänimikkeet muuttuvat oppiaineita laajempiin tiedonaloihin. Vaikka kouluissa edellytetään opettajilta entistä laaja-alaisempaa osaamista, koulukasvatus nojautuu kuitenkin vakiintuneiden tiedonalojen perusteiden opetuksen ja oppimisen tuntemiselle. Monen oppiaineen didaktiikan tutkimusperustainen kehittäminen opettajankoulutusyksiköissä on vähäistä, koska alan professuuria ei ole. Opettajankouluttajien tehtävänimikkeet kehittyvät ja nimikkeet kertovat siitä, millainen opetustarve kulloinkin yksilöissä on ja minkä alan edistämistä pidetään tärkeänä.

Kartoitus kuvaa eri yksiköiden hallinnollista rakennetta, opiskelijavalintoja ja koulutusaloja. Kartoituksesta ilmenee, että eri yksiköiden hallinnollinen rakenne, opiskelijavalinnat ja koulutusalat ovat erilaisia. Tämä on luonnollista, koska yliopistoilla on tutkimuksen ja opetuksen autonomia. Siten Ruotsin kaltainen malli keskusjohtoisesta opettajankoulutuksen opetussuunnitelmasta ei sopisi suomalaiseen yliopistopohjaiseen opettajankoulutukseen. Opettajankoulutuksella on kuitenkin kansallinen tehtävä ja osaamistarpeet muuttuvat. Kansallinen keskustelu ja opettajankoulutuksen kehittämiseen tähtäävä tutkimus ovat tarkoituksen mukaisia keinoja suunnata ja ohjata opettajankoulutusta.

Tässä vuoden ensimmäisessä numerossa on kirja-arvostelun lisäksi neljä vertaisarvioitua artikkelia. Artikkelit käsittelevät identiteettiä ja kulttuuria tuoreella ja monipuolisella tavalla. Jukka Rantala ja muut tarkastelevat suomalaisten alkuperän kysymystä monitieteisesti, Marja Laine koulun ja eri oppiaineiden lähtökohtia identiteettityöhön ja Juha Luodeslampi ja Arniika Kuusisto uskonnon opettajan identiteettityötä. Lisäksi Kirsi Makkonen ja muut avaavat yhteisopettajuutta ja joustavaa ryhmittelyä matematiikan oppimisessa.

\section{Kalle Juuti, Seija Kairavuori ja Arto Kallioniemi}

Helsingin yliopisto, Kasvatustieteellinen tiedekunta 